\title{
A Historical Perspective of Deaf People and Its Constitution as a Means of Social Movement in Brazil, in Contemporary Times
}

\author{
Ingrid Karla da Nóbrega Beserra \\ Federal University of Pernambuco, Recife, Brazil
}

\begin{abstract}
This paper aims to present the historical constitution of the Deaf Movement (Movimento Surdo) and their respective events and claims in the national socio-political scene. Among the numerous social movements operating in the country and the world we identified the Deaf Movement while present in the social struggles and the poor visibility conferred on it in the context of listener culture, considering their undeniable importance in the current form of society. Search up from the use of surveys and interviews to understand this movement as the set of actions developed by the deaf community around the historical issues, identity, cultural, social and political. Among the many claims of this movement highlights the proposed bilingual education for deaf people seeking social knowledge of deafness would mean not only the best form of education for the deaf, but also for the maintenance/affirmation of deaf culture.
\end{abstract}

Keywords: social movement, the deaf community, deaf culture, education

\section{Introduction}

Deaf people, throughout history, have been and are still treated as disabled who do not have the ability to perform various activities, being deprived of rights, and their citizenship is not respected by not communicating orally and, considering not participating in the culture of hearing society.

In history, there are few records about deaf, particularly in Prehistory, in antiquity and the Middle Ages. Only it is known that these civilizations were dominated by listeners and the deaf were excluded from social life, noting that there have always been deaf, but they were not always respected or even recognized as human beings, reaching the concept that was virtually impossible the survival of a child "disabled" at this historic time, the justification lifestyle.

Over the civilizations there were various forms of treatment for deaf people: Egypt and Persia were considered privileged sent from the gods; in Greek society was the defense of the elimination of babies born "misshapen"; the Romans adopted the killing and threw them in the river or abandoned or were led to enslavement; in the Middle Ages remained discrimination with strong influence and interference of the Catholic Church; but it was in the Modern Age that began its institutionalization focused educational methodologies for the deaf.

Thus, in Modernity, it is that we started to think that these people needed to be educated to join and

Ingrid Karla da Nóbrega Beserra, Master, Social Worker, Social Service, Federal University of Pernambuco.

Correspondence concerning this article should be addressed to Rua General Venceslau Braz, nº 193/Bloco K-Apto 202. Bairro: Alberto Maia/Cidade: Camaragibe-PE/Brasil. Postcode: 54771-060. E-mail: ingridkarla.nobrega@gmail.com. 
participate in society. Currently the company, still does not recognize the deaf / them as a people with culture and own language, which causes prejudice, discrimination and obstacles to the participation of deaf people in society.

According to Strobel (2008), deaf people are subjects who share the customs, stories, common in traditions and belong to the same cultural peculiarities. Deaf people have capabilities equal to hearing people, but suffer from forms of limitation imposed by society built on a listener model, which focuses on the oral-auditory communication, ignoring and disrespecting the deaf culture.

Organizations of the deaf community ranging from the development of political practices to those involving sport and culture promoted by the deaf. Today there are dozens of organizations throughout Brazil.

The socio-political landscape is understood in this respect as a set of articulated and practices which result in social movements with resistance possibilities. It is agreed with Klein (1995): "the deaf community sees us deaf movements a chance to walk politics of resistance to 'listeners' hitherto hegemonic practices in different educational, social and cultural areas, as well as a space of struggle recognition of sign language and deaf identity."

It considers that the political development of the deaf movement had further deepening from the 1990s that period, social joints, marches and entities representing deaf in Brazil stood out in the search for security rights of this social group.

In the 2000s, it created the Law 10.436 of April 24, 2002, which is recognized as the legal means of communication and expression to Brazilian Sign Language (Libras) and other expression features associated with it.

The Deaf Movement has been active in the Brazilian socio-political-economic reality, represented by FENEIS (National Federation of Deaf Education and Integration). ${ }^{1}$ But as we know that reality is not disconnected from the globalization scenario-that "opened new challenges and horizons in the knowledge, instituting practical and theoretical dilemmas in analyzing the tangle moving field of classes and social groups, power structures, integration and fragmentation of religious tensions, ethnic and gender” (SIMIONATO, 2011).

\section{Analysis and Discussion}

The Deaf Movement now has members/activists scattered throughout the country. There is such an organization to use the internet, as a communication vehicle capable of meeting the needs of deaf people, to promote and encourage demonstrations, rallies, training courses, meetings and gatherings throughout the year. It may be noted in this regard the main "day of action" for its members (deaf and family): the Day of the Deaf-September 26-when they occur simultaneously marches and protests in some states of the Federation.

Such movement of citizens sharing values that feed the social forces of civil society, we can say that the movement has sent its shares in favor of social policies for effective citizenship of the deaf person.

The questions and the movement claims to unfold a broader reality of political conflict, which is triggered when opportunities and changing political constraints create incentives for the social actors (Tarrow, 2009). So the demand is fostered by public policies that respect/value the deaf identity and citizenship of the country.

\footnotetext{
${ }^{1}$ FENEIS is a charity, non-profit purpose socio-cultural, and educational assistance which aims to defend and fight for the rights of Brazilian deaf community. It is affiliated to the World Federation of the Deaf and its activities have been recognized as of Federal Public Utility, State and Municipal. She is still the main scavenging capabilities for collective action for the Deaf Movement. Available in: (http://www.feneis.com.br/page/apud Barros e Hora).
} 
It is important to consider that the struggles waged by the Deaf Movement have reached significant levels. One can cite, for example, the inclusion in the Brazilian Constitution of laws that guarantee the right to access and other rights to citizenship.

The movement claims encompass the entire social framework. It is in this form, the struggle for access to health care which falls on the need for Libras interpreters in hospitals. In respect of the area and accessibility fighting for use of electronic panels and the presence of interpreters in public use locations, such as banks, lottery shops, airports, bus stations, stations. In relation to sport and leisure, the movement has sought public spaces that enable the experience of these rights; this search lies, for example, the struggle for existence subtitles in Brazilian films. Besides the issue of education that came up turning into one of the largest spaces of struggle for ensuring law and deaf culture.

The debate on the motion in question comprises an analysis of the discussion about whether or not the new social struggles or social subjects. However, it is not for us here to place the Deaf Movement in such a broad debate.

\section{Actions Developed for Deaf Community and the Proposed Education Bilingual}

The Movement Deaf on social situations that are exposed and which were previously identified establishes actions that claim and make concrete their questions around the historical issues, identity, cultural, social and political.

Their actions are implemented on specific dates, all in the ninth month of the year, being characterized as Blue September, this month marks the memory of deaf people, their struggles and achievements. Joins the blue color that symbolizes the deaf community and is present in the loop representing the concept of BE DEAF.

The Deaf Movement conducts activities in all states of Brazil during the month of September, seeking to mobilize the authorities and society to guarantee human rights, linguistic and cultural Deaf Community. The September Blue provides seminars, lectures, theatrical performances, marches, public hearings, exhibitions, parties, etc. in order to draw the attention of political authorities, the media and society to the needs of deaf and deaf culture, because although the Brazilian law to guarantee them a number of rights, many of these are not properly respected.

Among the main events planned are: The State Seminar on Defense of the Bilingual Schools for the Deaf in the NAP, an event that will take place in all the country's capital in order to make any proposals for amendments related to deaf education; the demonstration by the World Day of Sign Languages, in order to enhance respect and promote the recognition of sign languages; and the National Day of the Deaf on September 26 when social activities and various policies are held throughout the country, to defend the rights of the deaf.

True inclusion of deaf people in society begins with respect for their linguistic and cultural difference. We defend freedom of expression of the deaf and their rights of choice, supported in human and linguistic rights. (FENEIS, 2011)

The main demands of the Deaf Movement are pled in: accessibility of communication and information, particularly in organs, places and public services; accessibility and communication pounds in hospitals and other health units; jobs for the deaf, especially in inner cities; support and encouragement to sports practiced by the deaf; free pass; respect, dissemination and exploitation of Libras (Brazilian Sign Language) and the deaf culture; and in other claims, the very Deaf Movement took upon himself this as the greatest need for the realization of culture and deaf identity, not disparaging the important role of the other, the proposed bilingual 
education for the deaf.

It highlights that the proposed bilingual education for deaf seeks social recognition of deafness for deaf community would not only how best to educate deaf but also represent the maintenance/affirmation of deaf culture, claiming the social recognition of deafness.

The bilingual proposal does not privilege one language, but want to give right and conditions to the deaf individual to be able to use two languages; therefore, it is not denial, but of respect; the individual will choose the language they will use in each linguistic situation you are in. This proposal takes into account the characteristics of the deaf themselves, including the views of deaf adults in relation to the educational process of the deaf child. (KOZLOWSKI, 1998)

Bilingualism assumes that the deaf must master as mother tongue, sign language, which is their natural language, and as a second language the official language of their country. Therefore, it is extremely important the interaction of deaf children with other older deaf, who can master the sign language. Also, if the parents are listeners, there is the need for them to learn sign language, preferably in contact with deaf communities, to ensure a linguistic environment suitable for the deaf child, both within the family and the social (SMITH, 2001).

The effective participation of the Deaf Movement in the discussion of this proposal for bilingual education is of fundamental importance, therefore, the best way of teaching the deaf child is to give him a language development situation within a communication climate effective basis for all development the child's language.

The understanding that people have is that bilingual education cannot be seen only as a point of arrival, but as a starting point, whose political perspective reflects the socio-economic, linguistic and cultural rights of deaf people. It is a proposal that needs to be built with the deaf community, so that the political-pedagogical projects of bilingual education are not restricted only to the establishment of schools, but that could strengthen and create massively conditions "access to sign language and the second language, personal and social identity, meaningful information to the world of work and the deaf culture" (SKLIAR, 1997).

Regarding the Brazilian Education, the movement, according to FENEIS, proposes the public school system for the creation of deaf schools with bilingual approach from preschool to high school; offers undergraduate and graduate programs in public and private schools for the training of deaf teachers, bilingual teachers listeners and performers of Brazilian Sign Language; discusses with federal prosecutors and state the establishment of quotas for entry and deaf staying in Brazilian Universities; proposes and monitors continuing education courses for deaf education professionals (deaf teachers, trainers, listeners bilingual teachers, interpreters, etc.), from kindergarten to higher education, according to deaf needs; promote the production of educational material for deaf education and; promotes (FENEIS/Public Education Network) Pounds courses for the community, prioritizing deaf families.

Given this current discussion of the deaf community in their quest for realization/maintenance of deaf identity in the current socio-political context, the deaf movements in their performances guided actions, which these political subjects in joint action in various cities of the country claim in the different spaces of civil society, their rights in favor of strengthening the deaf culture.

\section{Conclusion}

It is understandable, therefore, that the Deaf Movement assume, given the current situation, which is to influence the various movements with its neoliberal ideology: fragmentation and flow of social struggles, an important role to question the social dynamic that is unfavorable to the strengthening of struggles. Deaf culture 
has great potential to leverage to a projection of their cultural characteristics through the listener culture.

This quest for the maintenance of deaf identity before a majority "listener" causes slight movement such discussions to the entire civil society, claiming respect for deaf culture and accessibility of this community in the various social spaces.

\section{References}

BARROS, J. P., \& HORA, M. M. da. (2009). Pessoas Surdas: Direitos, políticas sociais e serviço social (Deaf: rights, social policy and social work). Recife: Author's publisher.

BEHARES, L. E. (2000). Novas correntes na educação surda: dos enfoques clínicos aos culturais (New trends in deaf education: Clinical approaches to cultural). Santa Maria: UFSM.

GOHN, M. da G. (2010). Movimentos Sociais e redes de mobilizações civis no Brasil contemporâneo (Social movements and networks of civil mobilizations in contemporary Brazil). Petrópolis- RJ: Editora Vozes, (Publishing Vozes).

KLEIN, M. (1995). Movimentos Surdos e os Discursos sobre Surdez, Educação e Trabalho: A constituição do surdo trabalhador (Deaf movements and the discourses on deafness, education and work: The constitution of the deaf worker). Retrieved from http://www.cefetes.br/gwadocpub/Pos-Graduacao/Especializa\%C3\%A7\%C3\%A3o\%20em\%20educa\%C3\%A7\%C3\%A3o\% 20EJA/Publica\%C3\%A7\%C3\%B5es/anped2001/textos/t0359743704736.PDF. Acesso em: 09 de julho de 2015

KOZLOWSKI, L. (1998). A proposta bilingue de educação do surdo (The proposal of bilingual deaf education). Revista Espaço. INES.

MONTEIRO, M. S. (2015). História dos Movimentos dos Surdos e o Reconhecimento das Libras no Brasil (History of movements of the deaf and the recognition of pounds in Brazil). Retrieved from http://www.feneis.org.br/page/Editorial.asp

SANCHES, C. (1991). La educacion de los sordos en un modelo bilingue (The education of the deaf in a bilingual model). Iakonia. Venezuela.

SCHERER-WARREN, I. (1999). Cidadania sem Fronteiras-ações coletivas na era da globalização (Citizenship without Fronteiras-collective actions in the age of globalization). São Paulo: Editora Hucitec.

SILVA, V. (2001). A LUTA DOS SURDOS PELO DIREITO À EDUCAÇÃO E AO TRABALHO, capítulo: EDUCAÇÃO BILÍNGÜE: O INÍCIO DE UMA NOVA LUTA (THE FIGHT OF DEAF FOR THE RIGHT TO EDUCATION AND TO WORK Chapter: BILINGUAL EDUCATION: THE BEGINNING OF A NEW FIGHT A LUTA DOS SURDOS PELO $\begin{array}{lllllll}\text { DIREITO À } & \text { EDUCAÇÃO } & \mathrm{A} & \mathrm{AO} & \text { TRABALHO) } & \text { Retrieved }\end{array}$ http://www.sj.cefetsc.edu.br/ nepes/docs/nepes_dissertacoes/a_luta_surdos_direito_educacao_trabalho.pdf

SIMIONATTO, I. (2015). Questão Social e Pós Modernismo. As expressões ideo-culturais da crise capitalista na atualidade e sua influência no Serviço Social Social and Post Modernism question. (Ideoculturais expressions of the capitalist crisis today and its influence $\quad$ on $\quad$ social $\quad$ work). http://www.internacionaldelconocimiento.org/documentos/ponenciascompletasm4/Ivette\%20Simoniato.pdf

SKLIAR, C. (1997). La educación de los sordos: Una reconstruccíon histórica, cognitiva y pedagógica (Education of the deaf: A historical, cognitive and pedagogical reconstruction). Mendonça: EDIUNC.

STROBEL, K. L. (2006). A visão histórica da in (ex) clusão dos surdos nas escolas (A historical overview of in (exclusion) of deaf people in schools). Educação Temática Digital. 7(2), 244-252.

TARROW, S. (1998). O Poder em Movimento (The Power Moving). Petrópolis-RJ: Editora Vozes, (Publishing Vozes).

http://www.feneis.com.br/page/

http://www.marianahora.blogspot.com/

http://lutas-surdas.blogspot.com/

https://sinalizandodf.wordpress.com/

http://pt.scribd.com/doc/36689480/LEI-10436-2002-Dispocao-sobre-a-Lingua-de-sinais-Libras 